\title{
On the Norm Memes in English Translation of Classics-A Case Study of the Translation of the Works by Jiangxi Native Literati in the Song Dynasty $^{*}$
}

\author{
Yuying Li \\ Foreign Language College, Jiangxi Normal University, Nanchang, China \\ Wandi $\mathrm{Hu}$ \\ Foreign Language College, Jiangxi Normal University, Nanchang, China
}

\begin{abstract}
With the convening of the 19th NCCPC and at the call of "Building stronger cultural confidence and helping socialist culture to flourish." the going global of Chinese cultural classics has gained increasing importance. Jiangxi Province is the birthplace of literati and scholars throughout the ages, especially in the Song Dynasty. Among the Eight Great Literati of the Tang and Song Dynasties three were JX natives. Therefore, the study on the English translation of the classic works by them would be of great academic and practical values as well as significance for popularization. Taking Chesterman's Translation Memetics as the guidance and from the aspects of Expectancy Norms and Professional Norms, the study analyses and explores the translation strategies and skills of Chinese classic, in the hope to contribute the author's pygmy to the translation and spread of traditional Chinese culture.
\end{abstract}

Index Terms-memetics, translation norms, Jiangxi native literati in the Song Dynasty, English translation of Chinese classics

\section{INTRODUCTION}

Jiangxi Native Literati as Ouyang Xiu, Yan Shu, Huang Tingjian, Zeng Gong, Wang Anshi, Zhu Xi and Wen Tianxiang, etc. in the Song Dynasty have made great achievements in various genres of literary creation, enormously promoting the flourishment of Chinese classical culture. However, the studies on the translation of their works have not drawn adequate heed from the academic circles. Translation Memetics, with the ideas of replicating and transmitting cultural factors, is consistent with the cultural transmitting notion in the studies on English translation of classics. Based on Toury's Translation Norm Theory, Chesterman created norm memes, the core concept of his Translation Memetics, and divided it into expectancy norms and professional norms. Taking some works by Jiangxi Native Literati in the Song Dynasty as examples and from the two aspects of translation norm memes, through the comparison of the source texts and the target texts, the study arrives at a conclusion that it's proper to adopt the thick translation as a main strategy combined with Chinese-type English and other translation skills as addition, omission, and compensation, etc. in the hope to improve the quality of translation, enhancing the awareness of cultural exportation, spreading excellent culture and reproducing lingering charm of Chinese classics by Jiangxi literati in the Song Dynasty.

\section{TRanslation Memetics}

Meme is a term created, on the basis of Darwinism, to depict the factor in cultural transmission, as the way gene in genetic inheritance. Later it was introduced into translation study by Chesterman in his work Memes of Translation-The Spread of Ideas in Translation Theory, formulating Translation Memetics, a new branch of theory in translation study. The monograph mainly deals with value memes, norm memes and strategy memes, among which norm memes are further divided into expectancy norms and professional norms, the former being "established by the expectations of readers of a translation (of a given type) concerning what a translation (of this type) should be like" (Chesterman, 1997, p64); the latter are subordinate to the former, controlled by expectancies and influenced by the existing norm-authorities and other strong memes. Professionals refer to the translators who are responsible for translation integrity, and who are concerned about whether the translation can satisfy the current expectancy memes or not.

\footnotetext{
${ }^{*}$ Sponsored by Social Science Planned Research Project of Jiangxi Province in 2015
} 
From the perspective of Translation Memetics, the foremost expectancy norms to be followed nowadays in the English translation of Chinese classics are that the translators wish to spread the Chinese traditional culture and the target readers are inquisitive about the magnificent civilization. According to such strong expectancy memes, the discussion about professional norms which guide the translating process should be from various angles, such as the translator's responsibility, informative communication, the relationship between the source text and the target text, etc.

\section{APPlicAtion OF NORM Memes}

"If a meme comes to dominate (for any reason: practical, political, cultural, aesthetic...), and competing memes fade, on course of development is that such a meme becomes regarded as a norm-whether imposed by an authority or simply accepted as such." (Chesterman, 1997, p51) During the translating process, memes function as norms, retaining the feature of reproduction and dissemination while intervening in the relationship between the source texts and the translator, specifying translational action, keeping the quality of the translated version up to the expectancy of professionality, so the expectancy norms and the professional norms come into being.

\section{A. Expectancy Norms}

"When translators do what is expected of them, they will be seen to have done well." (Herman, 1991, p166) Therefore, as a product norm, the establishment and transmission of the befitting the expectancy norm memes may guide the translators to flexibly choose translation strategies and skills in terms of the acceptance and satisfaction of the expected readers.

\section{Aesthetic Appeal}

The immutability of the charm of the classics relies not only on its philosophy, literariness and delights in content, but also on the beauty of its linguistic features, such as those in Metrical Poetry and Yuefu Poems, which conforms to readers' various aesthetic tastes in language structure, rhythm, and so on. Therefore, in the course of classic translating, it's essential to consider how to reproduce the original form according to the needs of the author, the readers, the clients or other related people while delivering the original information.

\section{Example 1:}

ST: “深闺静几试笔墨, 白头腕中百斛力。 荣荣枯枯皆本色，悬之高堂风动壁。” (黄庭坚《姨母李夫人墨竹二首》其一)

TT: "At her quiet desk, deep in her chamber, exploring with brush and ink; Her hair is white, but a hundred pounds of force move in her wrist. Flourishing branches, withered twigs, each is as it is. Hang it in a great hall; the wind would shake the walls!"

Analysis: Jiangxi Province is one of the main producing areas of black bamboo. Advocated by the artists Wen Tong and Su Shi, the Chinese ink and wash painting about black bamboo was in vogue. Then, many eminent artists emerged in the Song Dynasty, and Mrs. Li, Huang Tingjian's aunt, was one of them. The poem was created to eulogize her excellent drawings of black bamboo and unfold the cultural meanings of the plant - the spirits of grittiness and integrity. The ST is a quatrain with seven characters in each line, the first line being unrhymed, but the second and the fourth lines rhyming couplets. Because of the language differences, the TT cannot be translated with the same rhyming sounds as the original, so the translator takes information communication as the premier aim to translate the first three lines. But the last line is distributed into two parts with “悬之高堂” and “风动壁” being separated by a semicolon in terms of sense groups, presenting a logical relationship between the two parts; then, the translator replicates the aesthetic meme - phonology beauty of the original to translate the two short sentences into rhyming couplets by using language compensation to highlight the original poem's peculiarity in rhyme. From the above, the target version meets the expectations of the readers on the rhyme and rhythm of Chinese quatrains, and the auditory expectation meme are successfully spread.

\section{Example 2:}

ST: “喧喧杂虏方满眼, 犋皎丹心欲语谁。 延寿尔能私好恶, 令人不自保妍媸。

丹青有迹尚如此，何况无形论是非。

穷通岂不各有命, 南北由来非尔为。”

(曾巩《明妃曲二首》其一)

TT: "Filling her eyes were none but clamorous caitiffs;

To whom could she talk about her heart of loyalty?

How could you, Yanshou, selfishly distort loveliness and repulsiveness,

So that beauty and ugliness could not be kept as they are?

Even a painting of the perceptible could be like this;

How can right and wrong be decided in their formlessness?

Frustration or success-isn't it in each person's lost? 
South or north-the difference is not just made for you."

Analysis: The Song Dynasty is the prime of the economy and culture of Jiangxi; however, as the significant traffic stronghold and military fort, JX was politically fluctuated by the domestic strives and aggressions from the Liao Regime of Khitans, the Western Xia Regime of Tanguts and the Jin Regime of Jurchens. As there was a historic tale about Wang Zhaojun who was sent to marry the ruler of Huns, a minority nationality to make peace, Zeng Gong adapted the story into Song of Brilliant Lady to convey his vehement national consciousness. Therefore, transmitting the culture with Chinese characteristics is an important purpose of translating classics. As an extraordinary literary genre, Chinese poetry shows unique features of Chinese both in content and form. The original poem is a metrical poetry with seven characters in each line. Among the rigid standards in rhyme and language structure, it is prescribed that the second to eight lines should be matched in sound, meaning or structure. In this case, the Chinese characters “喧喧” and “佼佼” are matched both in sound and structure, “好恶” and “妍媸”, “有迹” and “无形”, as well as “穷通” and “南北” are all matched in meaning and structure. The 2, 4 and 6 lines are translated as questions, which can be clearly taken as antithesis. In addition, since the odd line “穷痛岂不各有命” is the last rhetorical question in the text, and while all the translated lines with questions are even ones, it is better to make the structure of the two sentences different with that of the previous. Hence, in TT, the phrase "strategy or success" and "south or north" are matched both in meaning and structure through the way which the original text works, but the translator adds dashes following the phrases to prominently show the form similarity to the Chinese poem. Furthermore, the 4 couplets of "question + declarative sentence" form a series of parallelism, which strengthen Zeng's grief and indignation caused by the unrest of the Song Dynasty. On the whole, the translated version replicates the form meme of the source language, which satisfies the readers' curiosity for the unique form of Chinese metrical poetry, and eventually, the visual expectation meme disseminates more widely.

\section{Regional Cultural Characteristic}

Cultural factors are one of the most important issues in cross-cultural activities, and how to handle culture-loaded words is the key point and the difficulty in English translation of classics. It's a topic worthy of study to dig out the cultural connotation underlying the texts and to fluently express those deep meanings while avoiding the obstacles caused by cultural differences. The readers have the passion for knowing more about the excellent traditional culture in Chinese classics, and the translators themselves have an expectancy to choose proper translation methods in order to help their works win favorable feedbacks.

\section{Example 3:}

\section{ST: “日自午以前是神, 午以后是鬼。月自初三以后是神, 十六以后是鬼。”} (黎靖德《朱子语类》)

TT: "In the day, forenoon is the positive spiritual force; afternoon is the negative spiritual force. In the month, from the third day onward is the positive spiritual force; after the sixteenth day, it is the negative spiritual force."

Analysis: The ST is excerpted from The Analects of Zhu Xi which comprises the sayings in the form of answers \& questions by Zhu Xi and his disciples. The example illustrates Zhu's view of the images of “神” and “鬼”. The two in Chinese traditional culture are different with "god" and "ghost" in western culture in some cases, even though they are all supernatural species existing outside the external world. In the West, there are so many meanings leeched on to devil and god. For example, in Dante's The Divine Comedy, the two are opposite. "Devil" refers to the image who is awkwardly ugly and wicked, and "god" is the master of the universe and incarnation of justice; however, in China, “神” and “鬼” derive from Taoism and Buddhism. The former stands for Yang (the male principle in Chinese philosophy), referring to the deities or spirits of myriad things which are active, light, and positive, and the latter stands for Yin (the female principle in Chinese philosophy), referring to the dissipated souls along with the dead. The original author Zhu $\mathrm{Xi}$ is an epitome of the study on Confucianism, so most of what he said and what he has done reflect Confucianism. As a significant integrant of Chinese traditional culture, Confucianism has a high position that cannot be toppled. Therefore, the translator replicates the Chinese Neo-Confucianism memes, translating “神” as "the positive spirit force” and “鬼” as "the negative spirit force". Compared with "god" and "ghost/ devil", the two translated phrases have wider meanings while keeping form beauty, so it is easier to rouse the readers' interests in Confucianism. Above all, it's admissible to translate the culture-loaded words by copying some strong cultural memes from the source language to the TT.

\section{Context Effect}

Interlinear gloss is a special kind of annotation placed between the original text and its translation which helps readers realize the relationship between the source text and the translated version, and understand the context better.

\section{Example 4:}

ST: “或为渡江楫, 慷慨吞胡羯。”

(文天祥《正气歌》)

TT: “huo` wei' du` jiang- ji', kang- kai ${ }^{\wedge}$ tun- hu' jie'.

Or it is the oar during the River crossing - the fervency swallows up the barbarians.

Oar during the River crossing: this refers to the $313 \mathrm{C}$. E. event when $\mathrm{Zu}^{\wedge} \mathrm{Ti}^{\wedge}$ 祖逖 crossed the Yangtze River (Yangtze Jiang or Chang Jiang) leading his men north to recover territory lost to the Xiong Nu barbarians: halfway across $\mathrm{Zu}$ Ti struck the water with an oar and said: "If I, Zu Ti, cannot clear the Central Plains and restore sustenance to 
the people, then let me be like this big river!（祖逖不能清中原而复济者, 有如大江! ) ” He succeeded in recapturing all land south of the Yellow River and in holding that land against the Xiong Nu up to his death in $321 \mathrm{C}$. E."

Analysis: In the translated version, Chinese phonetic alphabets are notated between the source text and the target text, such as "huo' Wei' du` Jiang- Ji', kang- kai ${ }^{\vee}$ tun- $\mathrm{Hu}^{\prime}$ Jie". The special annotation is beneficial to the comparison of the TT and the ST. Such interlinear gloss is favorable for readers to understand the form of Chinese ancient poetry-five characters in each line. What's more, the translator adopts overt translation and annotated the literary quotation "oar during the River crossing” (“渡江楫”) below the translated text without destroying the fluency of the TT. At the same time, the note about the story of Zu Ti is a worthy supplement to associate his virtue with Wen Tianxiang' s spirit of integrity, which is more conducive for readers to comprehend the creation of The Song of the Spirit of Righteousness by Wen when he was in prison and appreciate the lofty moral courage as well as the strong patriotic spirit of ancient Chinese. Thus, it follows that interlinear gloss not only meets the readers' need for realizing the original structure but also fulfils their expectations for local culture in certain context, deepening the readers' comprehension of the original text.

\section{B. Professional Norms}

Compared with expectancy norm, professional norm regulates the translating process. According to Chesterman, it can be divided into three subsets - the accountability norm, the communication norm and the relation norm.

\section{Accountability Norm}

The target text is required to satisfy the needs of integrity and fidelity from the clients of the task, readers and so on. Hence, a professional translator has the responsibility to do his/her translation projects attentively.

\section{Example 5:}

ST: “忆昨九日访君时, 正见阶前两丛菊。 爱之欲绕行百匝，庭下不能容我足。

折花却坐时嗅之, 已醉还家手犹馥。

今朝我复到君家, 两菊阶前犹对束。”

(欧阳修《会饮圣俞家有作兼呈原父景仁圣从》)

TT: "I remember recently when I visited you on the festival of the ninth,

We happened to see before the terrace two bushes of chrysanthemums.

I loved them, and wished to circle them at least a hundred times,

But beneath your hall there wasn't even room to place my feet.

Plucking a flower, I withdrew to my seat, sniffing it now and then,

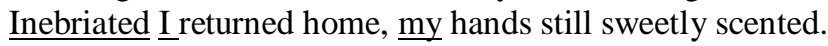

This morning, once again, I pay a visit to your house,

The two chrysanthemums before the terrace still oppose their clumps."

Analysis: Through depitcing the picture of drinking and enjoying the flourishing chrysanthemums on the Double Ninth Festival with his friend Mei Yaochen, Ouyang Xiu expresses his melancholy about fleeting hours and senility by chrysanthemum, a Chinese traditional image, and shows their peacefulness to aging and indifference to fame and wealth by drinking with old friends. In accordance with the differences between Chinese in parataxis and English in hypotaxis, the translator adds the words "I", "we", "you" and "my" to clarify the relationship between the object and the subject, which makes the ownership more clearly. In addition, the method of translating “九日” into "the festival of the ninth" by refication is beneficial for the readers' interpretation in that "the ninth day" here refers in particular to a Chinese traditional festival. Besides, the retention of the image "chrysanthemum" enables the readers to comprehend the spirit of steadfastness, immaculacy, the profound friendship and other cultural connotations often used in ancient Chinese poetry. The translation reflects the advantages of the replication of professional norm memes, completely disseminating the original ideas, and making the Chinese traditional image with sufficient meanings embraced by target readers.

\section{Communication Norm}

One of the important purposes of translation is communication, that is to say that the translator also plays the role of a communication expert who is responsible for communicating with the original author, the ST, clients, readers and himself/herself.

\section{Example 6:}

ST: “所谓教之之道何也? 古者天子诸侯, 自国至于乡党皆有学, 博置教道之官而严其选。朝廷礼乐、刑政之 事, 皆在于学, 学士所观而习者, 皆先王之法言德行治天下之意, 其材亦可以为天下国家之用。苟不可以为天 下国家之用，则不教也。苟可以为天下国家之用者，则无法在于学。此教之之道也。

...

所谓取之之道者, 何也? 先王之取人也, 必于乡党, 必于痒序, 使众人推其所谓贤能, 书之以告于上而察之。 诚贤能也, 然后随其德之大小、才之高下而官使之。所谓察之者, 非专用耳目之聪明, 而私听于一人之口也。 欲审知其德, 问以行; 欲审知其才, 问以言。得其言行, 则试之以事。所谓察之者, 试之以事是也。虽尧之用 舜, 亦不过如此而已, 又况其下乎? 若夫九州之大, 四海之远, 万官亿丑之贱, 所须士大夫之才则众矣, 有天 
下者, 又不可以一二自察之也, 又不可以偏属于一人, 而使之于一日二日之间考试其行能而进退之也。盖吾已 能察其才行之大者, 以为大官矣, 因使之取其类以持久试之, 而考其能者以告于上, 而后以爵命、禄秩予之而 已。此取之之道也。”

…...

\section{(王安石《上仁宗皇帝言事书》，即《万言书》)}

TT: "Instruction: in order to better prepare candidates for government offices, there should be a system of local and national schools with qualified teachers and a practical curriculum. While the current system of civil service examination should continue, it should test the candidates' specialized preparation for performing specific tasks in government (instead of reciting classics and writing essays). Furthermore, both civil administration and military training should be emphasized, as the purpose is to prepare competent personnel to properly manage the affairs of the state.

Recruitment: The recruitment of civil servants should be done in a decentralized manner with nominations solicited from throughout the country for decision by the throne. Candidates should be evaluated on their basis of their character, knowledge and ability to perform by means of their words and deeds over a probationary period by more experienced officials. Successful ones would be appointed and be entrusted with the task of recruiting another generation of officials."

Analysis: "Communication is, after all, a sharing." (Chesterman, 2012, p69). Therefore, according to the communication expectations of the target readers, the translator summarizes the main idea of the original by reducing the length of the text while the original sentence structures as antithesis, parallelism and rhetorical question are all neglected. In this letter to the Emperor Renzong of the Song Dynasty, Wang Anshi proposed his ideas on social reform, for instance, he persisted in observing strict rules for talents cultivation, and the original text reflects the thoughts. The first paragraph of the translation is a generalization of the Chinese passage with the omission of “天子诸侯”, “朝廷礼 乐” and other culture-loaded words, which means that excellent teachers and improved facilities should be disposed to train talents for the country. With the help of the translation, it's easier for the readers to avoid comprehension problems caused by cultural differences. In the second paragraph of the ST, the 5 to 7 sentences are taken as the gist of the TT with the reduction of Chinese ancient government positions like “士大夫” and the posthumous titles of the emperor like “尧” and “舜”, etc., as well as the examples supported to his ideas, so the length of the TT is shortened for realizing the main points of the letter quickly. Such translation is proper for the readers who are interested in Chinese ancient public management, where there is the embracement of the translation, there is the transmission of the credible communication memes.

\section{Relation Norm}

This norm concerns more about linguistic relationship between the original text and the translated text. For the English translation of Chinese classics, "equivalence" is too narrow a concept, it is just one of the relationships. "It is up to the translator to decide what kind of relation is appropriate in any given case." (Chesterman, 2012, p69)

\section{Example 7:}

ST: “然未发之前不可寻受, 已发之后不容安排。但平日庄敬涵养之功至, 而无人欲之私以乱之。则其未发也, 镜明水止; 而其发也, 无不中节矣。”

\section{(朱喜《中庸章句集注》)}

TT: "However, the state before the feelings are aroused cannot be sought and the state after they are aroused permits no manipulation. So long as in one's daily life the effort at seriousness and cultivation is fully extended and there are no selfish human desires to disturb it, then before the feelings are aroused it will be as clear as a mirror and as calm as still water, and the feelings are aroused it will attain due measure and degree without exception.”

Analysis: Compared with the professional norm memes mentioned above, the relation norm can be affected by the translator's thoughts with little hindrance. In other words, the relationship between the ST and the TT can be set as form similarity, style similarity, etc. by translators themselves on the basis of the rules both the accountability norm and the communication norm regulated. In the Song Dynasty, the Neo-Confucianism became the mainstream culture. Owing to the introduction and diffusion of Confucian culture to Nanchang (the provincial capital of JX) by Tantai Mieming (a Confucius disciple) when he visited the south, JX's local culture has grown to prosperity. Afterwards, Zhu Xi's Neo-Confucianism has greatly flourished JX's Confucian culture. In the ST, the phrase “镜明” and the verses “以铜为 镜, 可以正衣冠, 以史为镜, 可以知兴替, 以人为镜, 可以明得失。” from The Old Book of Tang. Legend of Wei Zheng (旧唐书.魏徵传) are intertextual. Moreover, the phrase “水止” and the sentence “公独何人，心如止水” by the poet Bai Juyi in the Tang Dynasty are intertextual, too. The two phrases embody a tranquil and peaceful mind through the metaphor. In order to introduce those figurative meanings, the TT retains them and changes the two Chinese $\mathrm{n}$. + adj. phrases “镜明” and “水止” into an English compound sentence with the subject “it" and the conjunction “and”, successfully keeping a relationship of semantic similarity with the ST.

\section{CONCLUSION}

Each of the expectancy norm meme and the professional norm meme has its own focus though the rules of the two overlapping in some aspects. The professional norms are controlled by the expectancy norms, so the translator should 
replicate and transmit the appropriate professional norm memes by various translation methods so as to meet the expectations of readers, clients, and even the translator himself/herself, etc. However, these norms are changeable, so it's necessary to breathe new life into the English translation of Chinese classics, an important mission to disseminate brilliant Chinese traditional culture by presenting and spreading more acceptable norm memes.

\section{REFERENCES}

[1] Ashmore, R. (2002). The Banquet's Aftermath: Yan Jidao's Ci Poetics and the High Tradition. T'oung Pao, 88(4-5), 211-250.

[2] Blackmore, S. (1999). The Meme Machine. Oxford: Oxford University Press.

[3] Chesterman, A. (1997). Memes of Translation-The Spread of Ideas in Translation Theory. Shanghai: Shanghai Foreign Language Education Press.

[4] Colin, H. (1999). Mundane Transcendence: Dealing with the Everyday in Ouyang Xiu's Poetry. Chinese Literature: Essays, Articles, Reviews (CLEAR), 21, 105-106.

[5] Distin, K. (2005). The Selfish Meme. Cambridge: Cambridge University Press.

[6] Drechsler, W. (2013). Wang Anshi and the Origins of Modern Public Management in Song Dynasty China. Public Money \& Management, 33(5), 353-360.

[7] Herman, T. (1991). Translation norms and correct translations. In Leuven-Zwart and Naaijkens (eds), 1991, 155-169.

[8] He, Z. R. (2005). Memes in Language. Linguistic Sciences, (06), 54-64.

[9] Jing, R. (2013). On Chan Wing-tsit's Transltion of Selected Philosophical Works from Chu Hsi: from the Perspective of Eco-translatology. Central China Normal University, 30+32-33

[10] Li, J. D. (1986). The Analects of Zhu Xi. Beijing: Zhonghua Book Company.

[11] Liu, X. (1975). The Old Book of Tang. Beijing: Zhonghua Book Company.

[12] Martin, J. P. (1998). Love and Marriage in Song China: Tao Yuanming comes home. Ars Orientalis, 28, 58

[13] Su, Y. H. (2015). On the Code-mixing Translation Strategy from the Perspective of Memes Mechanism. Foreign Language Research, (03), 107-110.

[14] Wang, A. S. (1999). The Complete Works of Wang Anshi. Shanghai: Shanghai Chinese Classics Publishing House.

[15] Xie, C. Q. \& He. Z. R. (2007). Memes and Communication. Journal of College of Chinese Language and Culture of Jinan University, (02), 46-52.

[16] Xu, Y. X., Ma, C. C. \& James, L. C. (2014). New development: Wang Anshi's Wanyanshu as the origins of modern public management?, Public Money \& Management, 34(3), 221-222.

[17] Yang, X. S. (2007). Wang Anshi's "Mingfei qu" and the Poetics of Disagreement. Chinese Literature: Essays, Articles, Reviews (CLEAR), 29, 71-72.

[18] Yu, J. L. (2016). A Memetic Study on Category Theory. Foreign Language Research, (02), $23-27$. http://www.tsoidug.org/Literary/Spirit_Righteousness_Comp.pdf.

Yuying Li was born in Jiangxi, China in 1964. She is currently a professor and master's supervisor in Jiangxi Normal University. Her research interests include theory and practice in English-China translation. Professor Li has hosted and finished a good dozen research projects at provincial level, published over 50 academic papers on translating and English language teaching and two sets of textbooks as well as some translations.

Wandi Hu was born in Jiangxi, China in 1993. She is a postgraduate student in the Foreign Language College of Jiangxi Normal University in China. Her research interests include theory and practice in English-China translation. She has published academic papers respectively entitled On Practical Translation from the Perspective of Memetics: A Case Study of the Chinese Translation of Convict Conditioning and On Domestication of Short Story: A Case Study of Zhang Jinghao's English Translation of Selected Short Stories of $O$. Henry, etc. 